\title{
Correlation between infection rate of triatominies and Chagas Disease in Southwest of Bahia, Brazil: a warning sign?
}

\author{
ELIEZER A. DA SILVEIRA ${ }^{1}$, ISRAEL S. RIBEIRO ${ }^{2}$, MIGUEL S. AMORIM ${ }^{1}$, DALVA V. ROCHA ${ }^{1}$, HELDER \\ S. COUTINHO ${ }^{3}$, LEANDRO M. DE FREITAS ${ }^{2}$, LAIZE TOMAZI ${ }^{2}$ and ROBSON A.A. DA SILVA ${ }^{2}$
}

\author{
'Controle de Doenças Endêmicas, Vigilância Epidemiológica, 20a Diretoria Regional de Saúde, Secretaria de \\ Saúde do Estado da Bahia, Rua João Pereira, s/n, São Vicente, 45000-115 Vitória da Conquista, BA, Brasil \\ ${ }^{2}$ Instituto Multidisciplinar em Saúde, Campus Anísio Teixeira, Universidade Federal da Bahia, \\ Rua Rio de Contas, 58, Candeias, 45029-094 Vitória da Conquista, BA, Brasil \\ ${ }^{3}$ Programa de Controle da Doença de Chagas, Vigilância Epidemiológica, Secretaria de Saúde \\ do Estado da Bahia, Avenida ACM, s/n, Iguatemi, 41820-300 Salvador, BA, Brasil
}

Manuscript received on October 20, 2015; accepted for publication on March 1, 2016

\begin{abstract}
Chagas disease, caused by the Trypanosoma cruzi, has a wide distribution in South America, and its main method of control is the elimination of triatomines. It is presented here the geographic distribution and the rate of natural infection by T. cruzi of triatomines collected and evaluated from 2008 to 2013 in southwest of Bahia. Triatomines were captured in the intradomiciliary and peridomiciliary areas of five cities located in the southwest of Bahia state, identified, and analyzed for the presence of trypanosomatids in their feces. During the study period the number of patients suspected for acute Chagas disease was recovered from the Notifiable Diseases Information System (SINAN). 8966 triatomines were captured and identified as belonging to eight species. Twenty-six presented themselves infected, being Triatoma sordida the most abundant and with the highest percentage of infection by T. cruzi. Tremedal was the city with the highest number of cases of acute Chagas' disease reported to SINAN. All cities showed triatomines infected with T. cruzi, so there is considerable risk of vectorial transmission of Chagas disease in the southwestern Bahia state, evidencing the need for vector transmission control programs and preventive surveillance measures.
\end{abstract}

Key words: Infection, Chagas disease, Trypanosoma cruzi, vector.

\section{INTRODUCTION}

The American trypanosomiasis is caused by the flagellate protozoan Trypanosoma cruzi. This pathology possesses a wide distribution, being estimated that there are about 7 million people infected by this protozoan and more than 70 million people live in areas of risk of infection.

Correspondence to: Robson Amaro Augusto da Silva

E-mail: robson.amaro@gmail.com
The control of vectors populations is one of the most used methods to prevent the transmission of T. cruzi since no vaccine is available to prevent infection and there is no cure during chronic phase (Marin-Neto and Rassi 2009, Mota-Sánchez 2009, WHO 2015).

The Triatominae subfamily was characterized as presenting 143 species that are subdivided into 18 genera and 5 tribes (Galvão et al. 2003, Frías- 
Lasserre 2010). They are characterized by their mouthparts as "pick-suction" that allows them to acquire parasites. Several studies have been conducted to understand the geographical distribution of its species and also their rate of infection (Guzmán-Marín 1990). It has been described different species of Triatominae in Brazil. In Rio Grande do Sul state (located at the south of the country) the most common triatomines are the Triatoma circummaculata and the Triatoma rubrovaria (Ribeiro et al. 2014); in Minas Gerais (located at the southeastern region), the most common are the Panstrongylus megistus and the Triatoma sordida (Belisário et al. 2013, Villela et al. 2005); The Brazilian northeast is a region that needs special attention regarding Chagas disease and the presence of vectors in its territory. It is already known that northeastern of Brazil is the second region with the largest triatomine infestation in the country, and the Bahia state in particular has the greatest diversity of species of triatomines in the country (Dias et al. 2000). In Pernambuco state, the species with the highest incidence are Triatoma pseudomaculata, Triatoma brasiliensis and the Pastrongylus lutzi (Silva et al. 2012). In Ceará state the species found are Panstrongylus lutzi, Triatoma pseudomaculata, T. brasiliensis and Rhodnius nasutus (Caranha et al. 2006, Freitas et al. 2004, 2005, Dias et al. 2008, Sarquis et al. 2004). In Bahia state, the most frequent species found are the Triatoma sordida, Triatoma sherlocki, Triatoma lenti, Triatoma tibiamaculata, Pastrongylus geniculatus and also Triatoma pseudomaculata (Dias et al. 2000, Santana et al. 2011, Ribeiro et al. 2014). In some regions in Bahia it is also found the Triatoma infestans, one of the main vectors of Chagas disease (Araújo et al. 2014, Rassi Jr et al. 2010, 2012).

Different studies have shown several infection rates of triatomine by $T$. cruzi. These infection rates vary from $6.4 \%$ (Ribeiro et al. 2014) up to $64.7 \%$ of microorganisms similar to T. cruzi (Sessa et al. 2002). The natural index of $T$. cruzi infection ranges from 10.8 to $30.2 \%$, depending on species and locations (Sarquis et al. 2004). In Bahia state, a recent study in Salvador and metropolitan area showed a $T$. cruzi infection rate of $54 \%$ of all insects analyzed, indicating a high potential risk for parasite transmission (Santana et al. 2011).

Since 2006, Brazil has been found free of vectorial transmission of Chagas disease by Triatoma infestans. However, the existence of dwellings whose physical conditions may favor their presence, keeps the risk of this species becoming domiciliated, and, thereby increasing the risk of infection by this route. In Bahia state, the routine actions of control programs are implemented depending on the infestation by the vector species and the epidemiological situation of the disease in the municipalities, defined by the classification according to the degree of risk of transmission. Of the total 417 existing municipalities, 101 (24.2\%) municipalities are classified as low risk, 219 (52.5\%) of medium risk and 97 (23.3\%) high risk.

Although eradication of vectors is somewhat impractical, control programs thereof have shown increasingly effectiveness, and this is represented by the decrease in seroprevalence numbers of Chagas disease in Brazil over the years. In a study conducted from 1975 (year that started the control program of the vectorial transmission of Chagas disease in the country) to 1981 , were observed seroprevalence of $8.8 \%$ in South and Southeast states, such as Rio Grande do Sul and Minas Gerais, and 5.4\% in Bahia (Camargo et al. 1984). In another study, conducted by Ostermayer et al. (2011) in Brazil, was observed a significant decrease in the seroprevalence percentages from 2001 to 2008 in children aged from 0 to 5 years old. In this study, the authors pointed out that the infection would be current, in which positive seroprevalence was $0.03 \%$.

Epidemiological analysis of the distribution of potential vectors for $T$. cruzi is an essential information, in order to have a better understanding of how the transmission of the parasite occurs, and 
from then on, articulate strategies to control the transmission of Chagas disease (Silva et al. 2012). Therefore, the present work aimed to analyze the distribution scenario of triatomines and their rate of natural infection with Trypanosoma cruzi in the southwest region of the state of Bahia from 2008 to 2013 .

\section{MATERIALS AND METHODS}

\section{COLLECTS}

Triatominae were captured, a quarterly frequency, during the period from 2008 to 2013 in the cities of Anagé, Caraíbas, Condeúba, Presidente Jânio Quadros and Tremedal, located in the southwestern region of Bahia (Figure 1). Specimens were collected after active searching manually with forceps and light, inspecting cracks, crevices and hiding places for these triatomines. The collection was carried by endemic control agents of the municipalities under the guidance of technicians from the 20th Regional Directorship of Health, the State Department of Health of Bahia.
TAXONOMIC IDENTIFICATION AND PARASITOLOGICAL RESEARCH

The triatomines were identified and forwarded to Triatomines Laboratory from the core control of endemic diseases of the DIRES20-SESAB (Vitória da Conquista/BA). Over there, the taxonomic identification was held. A parasitological survey was conducted by compressing the abdomen of triatomines and collecting fresh feces, which were used as a sample. These were properly treated and stained with Giemsa for subsequent analysis with an optical microscope, in which was conducted the search by Trypanosoma cruzi (Silveira and Sanches 2003). When found even a single individual of $T$. cruzi in triatomine, this was considered infected.

\section{NotifiCATION OF CHAGAS DiSEASE}

During the study period, 2008 to 2013, the patients suspected of acute Chagas disease were reported by the Departments of Health in each municipality through the Notifiable Diseases Information System (SINAN).
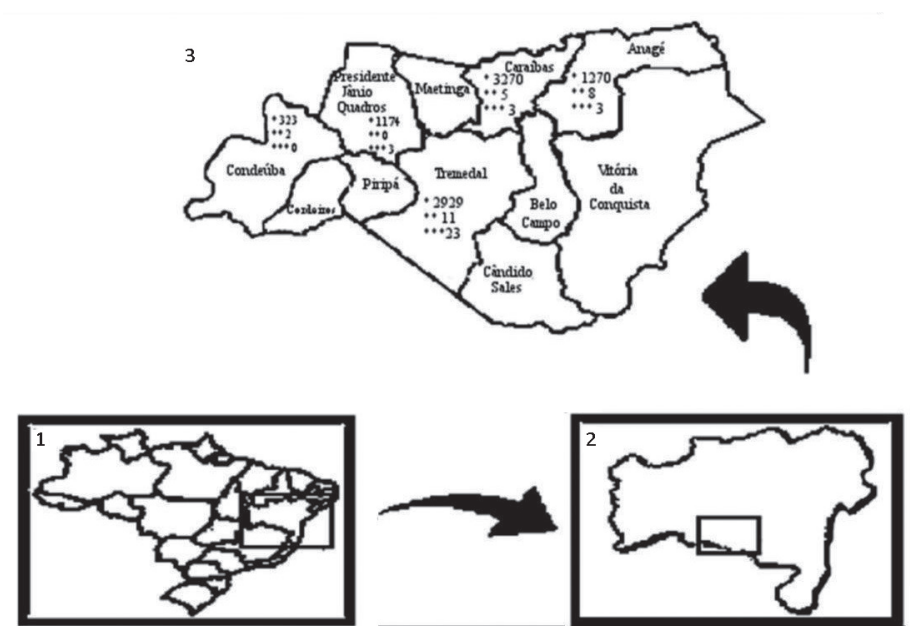

Figure 1 - Geographical distribution map of triatomines in the southwest region of Bahia. 1 - Brazil; 2 - Bahia; 3 - Southwest of Bahia. * - Total number of triatomines; $* *$ - Number of infected triatomines by flagellate protozoa similar to T. cruzi. *** - Number of patients with Chagas disease reported by SINAN system, period 2008 to 2013. 


\section{RESULTS}

A total of 8,966 triatomine from eight different species were collected, being 472 in the intradomiciliary and 8,494 in the peridomiciliary area, among the five cities analyzed within a period of six years (Table I). The species with the highest abundance was the Triatoma sordida (8,657/96.55\%), followed by Triatoma pseudomaculata (129/1.44\%), Pastrongylus geniculatus (78/0.87\%), Pastrongylus lutzi (52/0.58\%), Triatoma infestans (35/0.39\%), Triatoma melanocephala (12/0.13\%), Rodnius neglectus $(2 / 0.02 \%)$ and Triatoma vittceps $(1 / 0.01 \%)$ (Table II). Caraíbas was the city with the highest occurrence of triatomines, being captured until the end of this study 3,270 vectors. Soon after, appears Tremedal with 2,929, Anagé with 1,270, Presidente Jânio Quadros with 1,174 and finally Condeúba with the occurrence of 323 triatomine vectors captured (Table I).

As for natural infection of triatomine bugs vectors the results follow. From the total of captured triatomines only $26(0.29 \%)$ showed infection by T. cruzi through the parasitological test. Of these vectors, 19 were T. sordida (first in frequency in our study) $(73.08 \%)$ and 7 were $P$. geniculatus (third in frequency) (26.92\%). The remaining species showed no T. cruzi infection detectable. Among the cities, Tremedal had the highest number of infected triatomines, with 11 vectors $(42.31 \%)$, these being P. geniculatus (7) and T. sordida (4). In other cities, only $T$. sordida presented infected vectors, being eight in Anagé (30.77\%), five in Caraíbas (19.23\%) and two in Condeúba (7.69\%). Presidente Jânio Quadros showed no vectors infected by $T$. cruzi according to the parasitological test performed (Table III).

Among all cities, only Condeúba (fifth in occurrence vector) showed no reports of individuals diagnosed with acute Chagas disease in SINAN (Figure 1). In the cities of Anagé, Caraíbas and Presidente Jânio Quadros three cases were reported by each city. Tremedal was the city that had the highest number of acute Chagas disease reports in SINAN, totaling 23 cases. Following the description of years in which cases have been reported (data not shown). In Anagé all cases were reported in 2009. In Caraíbas all in 2013 and in Presidente Jânio Quadros only one case was reported in 2011 and two cases in 2013. In Tremedal, while 2010 was the year in which most reports occurred, with 12 reported cases, one case has been registered in 2008, two cases in 2009, two cases in 2011 and six cases in 2012, there is no recorded cases in the last year of the study (2013).

\section{DISCUSSION}

Currently, different strategies to control Chagas disease have been applied. Among them, there is the improvement of housing and surrounding areas in hazardous locations and also methods of sanitary education. All aimed to smaller infestation of triatomines, which are the main responsible vectors for disease transmission (Coura and Dias 2009). In Bahia, of the existing 336 municipalities, only 29 (in the extreme south) were considered without risk of vector transmission. In all others (282) were detected the presence of at least one major vector species (T. infestans, P. megistus, T. brasiliensis, T. pseudomaculata and T. sordida) (SESAB/ DIVEP 2006). In this study, Bahia, obtained from WHO (1991) certification of non-free zone for vector transmission by T. infestans, as well as 12 other states, but "possibly interrupted transmission". Methods based on the control and elimination of the vectors have been already used some decades ago, and were effective in reducing the transmission of Chagas disease, such as the control of Triatoma infestans in the late 60s and early 70s (Carvalho et al. 2011).

The present study showed a distribution of vectors in southwestern Bahia similar to the distribution in other regions of Brazil, mainly in the northeast and midwest. The Triatoma sordida Stal, 
TRIATOMINE INFECTION RATE AND CHAGAS DISEASE

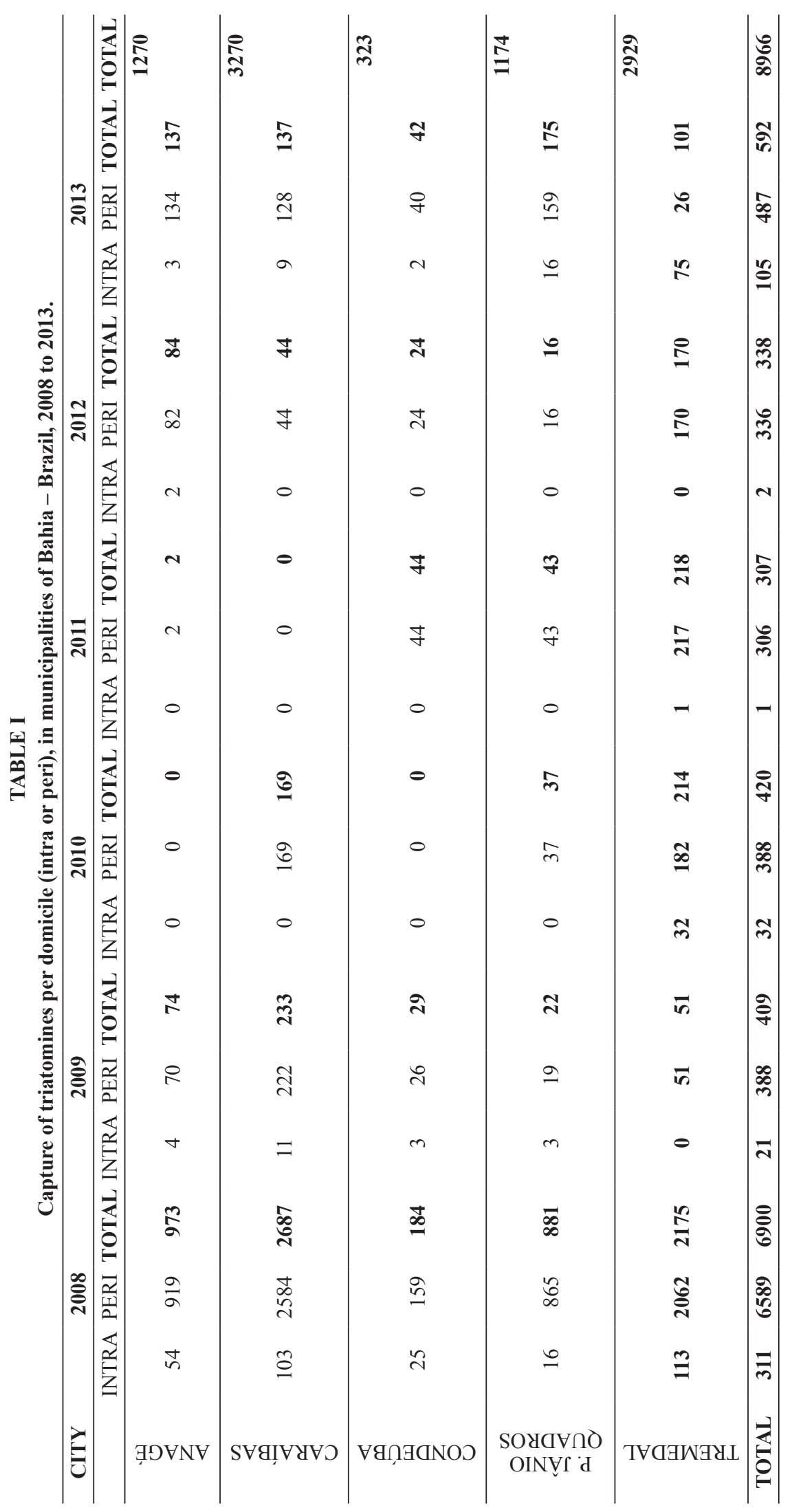




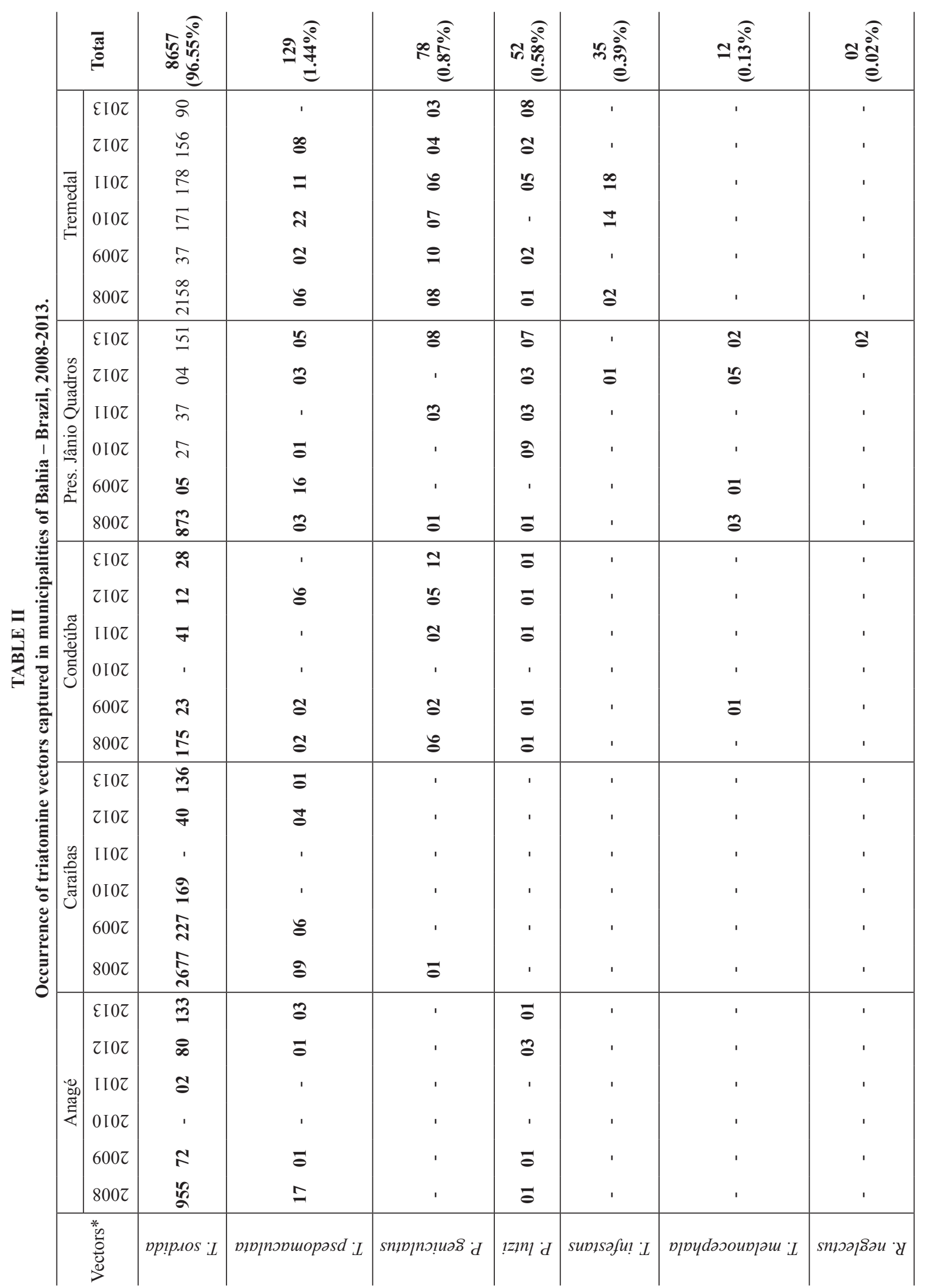



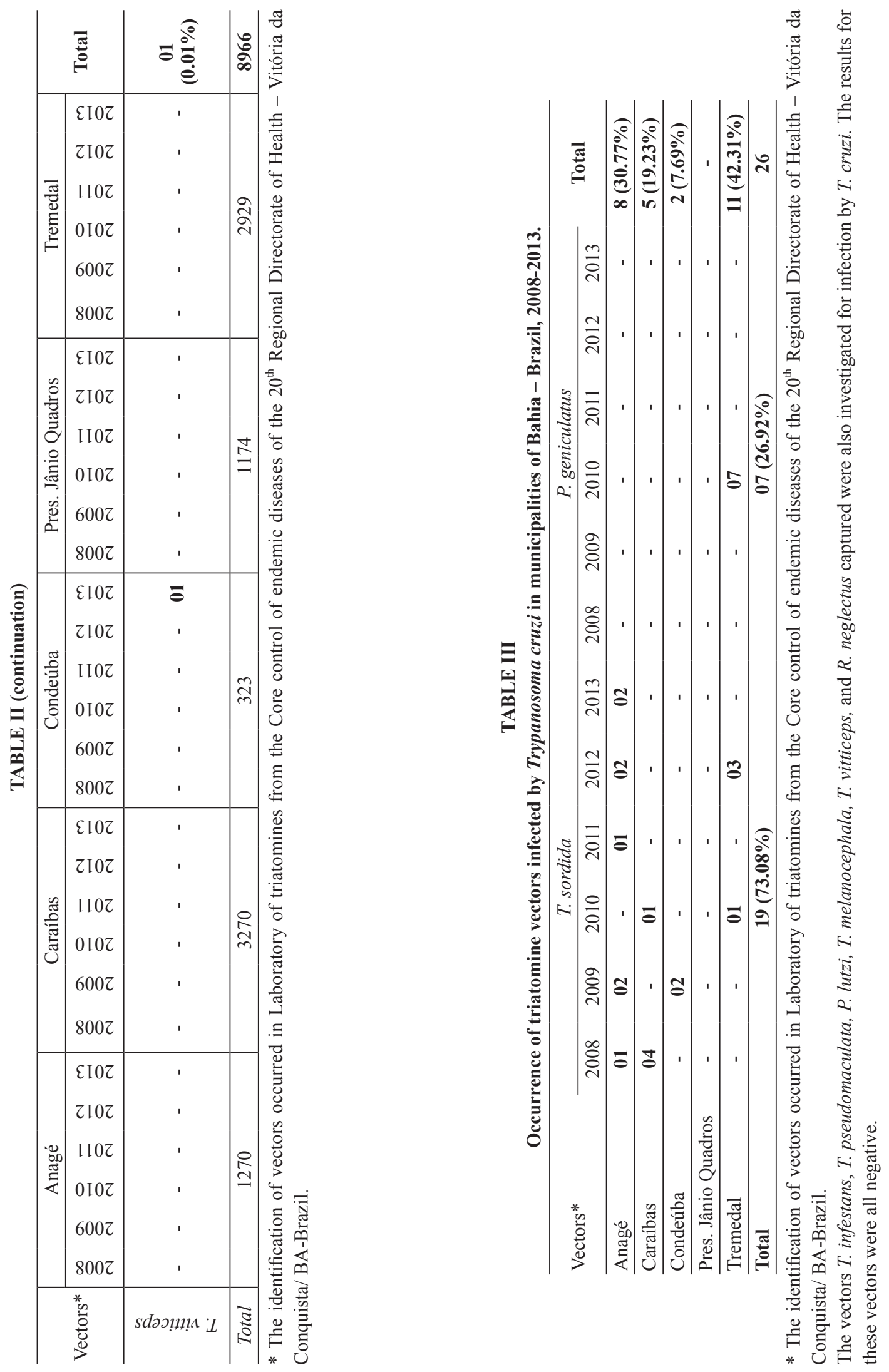
1859 (species with the highest occurrence in this study) showed also to be quite present in several states. According to Gurgel-Gonçalves et al. (2012), who conducted a study based on ecological niche model, $T$. sordida showed greater distribution in the Brazilian Cerrado, and it is present in virtually all the northeast, beyond the southeast and Brazilian central-western. Moreover, this appears to be the vector with the highest occurrence not only in this study (which analyzed southwestern Bahia) but also in other studies such as in the state of Goiás, where between the years 2000 and 2003 among 51,570 triatomines captured more than $86 \%(44,374)$ were from this species (Oliveira and Silva 2007). Another relevant factor regarding the T. sordida is that some of these insects already have been found resistant to deltamethrin, one of the chemicals used in programs to combat vectors (Pessoa et al. 2014).

The risk of transmission of the parasite by the T. sordida is considered low, since this usually does not dwell intradomicile regions and can be found more often in the peridomicile (Forattini et al. 1979). However, this is also more related to agricultural environments which require attention and control of this vector, since the cities analyzed consist of cities with agricultural activities; no major industrial centers; and there are still people who survive from the field work (Klink and Machado 2005). Similar to these studies, the frequency of T. sordida found by our work involves mainly agricultural counties.

The Triatoma pseudomaculata Corrêa \& Espinola, 1964 is considered one of the major triatomine in the northeast of the country, since it is present in all states of the region and has been considered the most prevalent vector in several northeastern states. For several years, this region was the epicenter of its origin and dispersion, and studies suggest that from the northeast these vectors infested other states, such as Minas Gerais and Goiás (Dias et al. 2000, Silveira et al. 2002). This species are generally present in peridomicile areas, dwelling mainly natural, being present generally in lofts, fences, roof spaces, tree holes and piles of firewood or bricks (Assis et al. 2007). However, in the specimens captured in intradomiciliary environments during our study, no infection has been observed by T. cruzi. Studies show that their presence has low conversion rates for metacyclic trypomastigotes, and in this way, T. pseudomaculata have not been considered an important vector of Chagas disease (Forattini et al. 1981, PerlowagoraSzumlewicz and Moreira 1994).

Other species in our study that presented infection by $T$. cruzi was Pastrongylus geniculatus Latreille, 1811, which presents a wide distribution throughout the country, but not restricted only to this, being widely distributed by Americas and present at least in 16 countries (Leite et al. 2007). Despite the highest rate of infection among the species analyzed in this study originally inhabits in the wild environment, and has not been considered such an important vector of $T$. cruzi because their bite is painful and cause allergic reactions, which hinders their efficiency of vector transmission (Diotaiuti 2009), it becomes necessary to take special care of this vector in these regions, since according to Marçal and Macêdo (2004), this species is migrating to the intradomiciliary regions.

Triatoma infestans Klug, 1834 was found in considerable numbers in our study, mainly in the city of Tremedal. In the early 1990s, this vector has demonstrated a geographic distribution of approximately $37,282.27 \mathrm{mi}$ and was responsible for the transmission of Chagas disease to about 9 million people (WHO 1991). It is noteworthy that Triatoma infestans was once considered one of the main vectors of Chagas disease in Brazil, mainly in the state of São Paulo. However, more recently, some states have already received certificate of disposal of this vector (Carvalho et al. 2011, Oliveira and Silva 2007). Older studies, such as Barrett et al. (1979) showed a large amount of this vector in the southwestern region of Bahia, both 
intradomicile and peridomicile, with 5\% infection rate, providing a high risk of transmission due to its efficiency as a vector. However, in 2006, Brazil received an International certification of elimination of transmission of Chagas disease by T. infestans, granted by the Pan American Health Organization (PAH), joining Uruguay and Chile, certified in 1997 and 1999, respectively (Schofield et al. 2006, Silveira and Dias 2011).

Despite the few cases of diagnosed patients reported, this study shows the possibility of a relationship between the number of infected triatomine bugs and the number of people reported with Chagas disease, since Tremedal was the city with the greatest number of insects infected and also with the highest number of cases reported in SINAN of individuals diagnosed with acute Chagas disease. However, in a study by Carvalho et al. (2011), it was observed that despite the high rate of infected triatomine, $50 \%$ positive for $T$. cruzi, in human only $1.2 \%$ were positive showing no direct relationship between the presence of infected triatomine vector and transmission to humans. Although, this same study observed that the average distance of triatomines collection points from the housing of individuals analyzed were $257.76 \mathrm{yd}$ and have not being considered peridomicile region, also, becoming a difficulty to the contact between humans and vectors in that region. Although our study makes no correlation between the housing of patients with acute disease and the distance from the site of capture of the insects, the cities where the data collections were performed are primarily agricultural.

Therefore, due to the capture of triatomines infected with $T$. cruzi in almost all the cities analyzed in this study, it was observed that in the southwestern region of Bahia there is a considerable risk of vector transmission of this parasite. Although they are considered less efficient species vectors than $T$. infestans, we reported $T$. sordida and $P$. geniculatus also infected. These data indicates that more atten- tion should be given and new strategies should be developed to control T. cruzi vectors in this region. This study was the first to show a clear need of entomological surveillance and monitoring of these potentially hazardous locations, beyond the awareness of the population about the possible locations of vectors infestation. However, more studies are necessary over the next few years to analyze if the sanitary measures taken are effective and evaluate new methods of control.

\section{ACKNOWLEDGMENTS}

We thank all the Chagas Disease Control Program staff attached to the $20^{\text {th }}$ Regional Board of Health and the Bahia State Health Secretariat involved in the collection and transport of triatomines. We also thank the municipalities for which data were reported through the Notifiable Diseases Information System (SINAN) and also to the financial support granted by Ministry of Health of Brazil.

\section{RESUMO}

A doença de Chagas, causada pelo Trypanosoma cruzi, possui uma ampla distribuição na América do Sul, e tem como principal método de controle a eliminação de triatomíneos. Apresenta-se aqui a distribuição geográfica e a taxa de infecção natural por T. cruzi de triatomíneos coletados e avaliados de 2008 a 2013, no sudoeste da Bahia. Os triatomíneos foram capturados nas áreas intradomiciliares e peridomiciliares de cinco cidades localizadas no sudoeste da Bahia, identificados e analisados quanto à presença de tripanossomatídeos em suas fezes. Durante o período de estudo o número de pacientes com suspeita de doença de Chagas aguda foi recuperado a partir do Sistema de Informação de Agravos de Notificação (SINAN). 8966 triatomíneos foram capturados e identificados como pertencentes a oito espécies. Vinte e seis apresentaram-se infectados, sendo Triatoma sordida o que mostrou maior percentagem de infecção pelo T. cruzi. Tremedal foi a cidade com o maior número de casos de doença de Chagas aguda relatado pelo SINAN. Todas as cidades apresentaram triatomíneos infectados com o T. cruzi, 
por isso, existe um risco considerável de transmissão vetorial da doença de Chagas no sudoeste da Bahia, evidenciando a necessidade de programas de controle de vetores de transmissão e medidas de vigilância preventiva.

Palavras-chave: infecção, doença de Chagas, Trypanosoma cruzi, vetor.

\section{REFERENCES}

ARAÚJO RF, MENDONÇA VJ, ROSA JA, MATOS JF, LIMA SCR AND FIGUEIREDO MAA. 2014. Description of a newly discovered Triatoma infestans (Hemiptera: Reduviidae) Foci in Ibipeba, State of Bahia, Brazil. Rev Soc Bras Med Trop 47(4): 513-516.

ASSIS GFM, AZEREDO BVM, FUENTE ALC, DiOTAIUTI L AND LANA M. 2007. Domiciliation of Triatoma pseudomaculata (Corrêa e Espínola 1964) in the Jequitinhonha Valley, State of Minas Gerais. Rev Soc Bras Med Trop 40(4): 391-396.

BARRETT TV, HOFF R, MOTT KE, GUEDES F AND SHERLOCK IA. 1979. An outbreak of acute Chagas's disease in the São Francisco Valley region of Bahia, Brazil: triatomine vectors and animal reservoirs of Trypanosoma cruzi. Trans R Soc Trop Med Hyg 73(6): 703-709.

BELISÁRIO CJ, DiAs JVL AND DiOTAIUTI L. 2013. Profile of the Trypanosoma cruzi vector infestation in Jaboticatubas, State of Minas Gerais, Brazil. Rev Soc Bras Med Trop 46(6): 779-782.

CAMARGO ME, SILVA GR, CASTILHO EA AND SILVEIRA AC. 1984. Inquérito sorológico da prevalência de infecção chagásica no Brasil, 1975/1980. Rev Inst Med Trop 26(4): 192-204.

CARANHA L, LOROSA ES, ROCHA DDS, JURBERG J AND GALVÃO C. 2006. Feeding sources evaluation of Panstrongylus lutzi (Neiva \& Pinto, 1923) (Hemiptera: Reduviidae: Triatominae) in the state of Ceará. Rev Soc Bras Med Trop 39(4): 347-351.

CARVALHO EOP, ROSA JA, CARVALHO AA, CHAVES HCO, SOUZA EA, OSTERMAYER AL AND CAMARGO LMA. 2011. Study on Chagas disease occurrence in the municipality of Monte Negro, state of Rondônia, Brazilian Amazon. Rev Soc Bras Med Trop 44(6): 703-707.

CARVALHO ME, SILVA RA, WANDERLEY DMV AND BARATA JMS. 2011. Chagas disease Control Program in the State of São Paulo, Brazil Seroepidemiological aspects of homogeneous geographic microregions. Rev Soc Bras Med Trop 44: 85-94.

COURA JR AND DIAS JCP. 2009. Epidemiology, control and surveillance of Chagas disease - 100 years after its discovery. Mem Inst Oswaldo Cruz 104: 31-40.

Dias FBS, BEZERRA CM, Machado EM, CASANOVA C AND DIOTAIUTI L. 2008. Ecological aspects of Rhodnius nasutus Stål, 1859 (Hemiptera: Reduviidae: Triatominae) in palms of the Chapada do Araripe in Ceará, Brazil. Mem Inst Oswaldo Cruz 103(8): 824-830.

DIAS JCP, MACHADO EMM, FERNANDES A AND VINHAES MC. 2000. General situation and perspectives of Chagas disease in Northeastern Region, Brazil. Cad Sau Pub 16(Suppl. II): 13-34.

DIOTAIUTI L. 2009. “Triatomine-vectors of Trypanosoma cruzi infection" in Emerging Chagas Disease. Teixeira A, Vinaud M and Maria Castro A (Eds), p. 24-39, Bentham Science Publishers.

FORATTINI OP, BARATA JMS, SANTOS JLF AND SILVEIRA AC. 1981. Hábitos alimentares, infecção natural e distribuição de triatomíneos domiciliados na Região Nordeste do Brasil. Rev. Saúde Pública 15: 113-164.

FORATTINI OP, FERREIRA AO, SILVA EOR AND RABELLO EX. 1979. Ecological aspects of South American trypanosomiasis. XV. Development, variation and permanence of Triatoma sordida, Panstrongylus megistus and Rhodnius neglectus in artificial ecotopes. Rev. Saúde Pública 13: 220-234.

FreItAs SPC, FreITAS ALC AND MONTE GONÇALVES TC. 2004. Occurrence of Panstrongylus lutzi, in peridomiciliary areas, State of Ceará, Brazil. Rev. Saúde Pública 38: 579-580.

FreITAS SPC, LOROSA ES, RODRIGUES DCS, FREITAS ALC AND GONÇALVES TCM. 2005. Feeding patterns of Triatoma pseudomaculata in the state of Ceará, Brazil. Rev. Saúde Pública 39: 27-32.

FRÍAS-LASSERRE D. 2010. A new species and karyotype variation in the bordering distribution of Mepraia spinolai (Porter) and Mepraia gajardoi Frías et al (Hemiptera: Reduviidae: Triatominae) in Chile and its parapatric model of speciation. Neotrop Entomol 39: 572-583.

GALVÃO C, CARCAVALLO D, ROCHAS AND JURBERG J. 2003. A checklist of the current valid species of the subfamily Triatominae Jeannel, 1919 (Hemiptera, Reduviidae) and their geographical distribution, with nomenclatural and taxonomic notes. Zootaxa 202: 1-36.

Gurgel-GonÇALVES R, GALVÃo C, Costa J AND PETERSON AT. 2012. Geographic Distribution of Chagas Disease Vectors in Brazil Based on Ecological Niche Modeling. J Trop Med 10: 1-15.

GUZMÁN-MARÍN E. 1990. Los transmisores de la enfermedad de Chagas. Rev Biomed 1: 144-153.

KLINK CA AND MACHAdO RB. 2005. Conservation of the Brazilian Cerrado. Conserv Biol 19: 707-713.

LEITE GR, SANTOS CB AND FALQUETO A. 2007. Insecta, Hemiptera, Reduviidae, Panstrongylus geniculatus: geographic distribution map. Check List 3: 147-152.

MARÇAL JR O AND MACÊDO HS. 2004. Distribuição de vetores da doença de chagas em nível domiciliar: um estudo na zona rural de Uberlândia (MG). Cam Geogr 3: 50-66. 
MARIN-NETO JA AND RASSI JR A. 2009. Actualización sobre La cardiopatía de la enfermedad de Chagas en el primer centenario de su descubrimiento. Rev Esp Cardiol 62: 1211-1216.

MOTA-SÁNCHEZ J. 2009. DNA Vaccines: Induction of the immune response. Salud Pública de Mex 51: 463-469.

OLIVEIRA AWS AND SILVA IG. 2007. Geographical distribution and indicators entomologic of sinantropic triatomines captured in the State of Goiás. Rev Soc Bras Med Trop 40: 204-208.

OSTERMAYER AL, PASSOS AD, SILVEIRA AC, FERREIRA AW, MACEDO V AND PRATA AR. 2011. The National Survey of seroprevalence for evaluation of the control of Chagas disease in Brazil (2001-2008). Rev Soc Bras Med Trop 44: 108-121.

Perlowagora-SzUMlewiCZ A AND Moreira CJC. 1994. In vivo differentiation of Trypanosoma cruzi -1 . Experimental evidence of the influence of vector species on metacyclogenesis. Mem Inst Oswaldo Cruz 89: 603618.

Pessoa GCD, Dias LS AND Diotaiuti L. 2014. Deltamethrin pyrethroid susceptibility characterization of Triatoma sordida Stål, 1859 (Hemiptera: Reduviidae) populations in the Northern Region of Minas Gerais, Brazil. Rev Soc Bras Med Trop 47: 426-429.

RASSI JR A, RASSI A AND MARIN-NETO JA. 2010. Chagas disease. Lancet 375: 1388-1402.

RASSI JR A, RASSI A AND REZENDE MJ. 2012. American trypanosomiasis (Chagas disease). Infect Dis Clin North Am 26: 275-291.

Ribeiro AR, MENDONÇA VJ, ALVES RT, MARTINEZ I, ARAÚJO RF, MELLO F AND RosA JA. 2014. Trypanosoma cruzi strains from triatomine collected in Bahia and Rio Grande do Sul, Brazil. Rev Saúde Pública 48: 295-302.

SANTANA KSO, BAVIA ME, LIMA AD, GUIMARÃES ICS, SOARES ES, SILVA MMN, MENDONÇA J AND MARTIN MS. 2011. Spatial distribution of triatomines (Reduviidae: Triatominae) in urban areas of the city of Salvador, Bahia, Brazil. Geospatial Health 5: 199-203.

SARquis O, Borges-Pereira J, CORd JRM, GOMES TF, CABELlO PH AND LIMA MM. 2004. Epidemiology of Chagas disease in Jaguaruana, Ceará, Brazil. I. Presence of triatomines and index of Trypanosoma cruzi infection in four localities of a rural area. Mem Inst Oswaldo Cruz 99: 263-270.

SCHOFIELD CJ, JANNIN J AND SALVATELla R. 2006. The future of Chagas disease control. Trends Parasitol 22: 583588.

SESAB/DIVEP - SECRETARIA DA SAÚDE DO ESTADO DA BAHIA/ DIRETORIA DE VIGILÂNCIA EPIDEMIOLÓGICA. 2006. Informe de situação do controle da doença de Chagas, com especial referência aos avanços logrados na interrupção da transmissão vetorial por Triatoma infestans. In: Silveira AC and Mendonça J (Orgs), Salvador: Secretaria de Estado da Saúde, Superintendência de Vigilância em Saúde.

SESSA PA, PIMENTEL RR, FERREIRA A AND FALQUETO LA. 2002. Chagas' disease seroprevalence among school-age children in Espírito Santo State, Brazil, 1999-2000. Cad Sau Pub 18: 1765-1769.

Silva mBA, BARreto AVMS, Silva HA, GAlvão C, ROCHA D, JURBERG J AND GURGEL-GONÇALVES R. 2012. Synanthropic triatomines (Hemiptera, Reduviidae) in the state of Pernambuco, Brazil: geographical distribution and natural Trypanosoma infection rates between 2006 and 2007. Rev Soc Bras Med Trop 45: 60-65.

Silveira AC, Arias AR, SEgura E, Guillén G, Russomando G, SCHENONE H, DiAs JCP, PADILla JV, LORCA M AND SALVATELLA R. 2002. O controle da doença de Chagas nos países do Cone Sul da América: História de uma iniciativa internacional 1991/2001, Faculdade de Medicina do Triângulo Mineiro, Uberaba, 316 p.

SILVEIRA AC AND DIAS JCP. 2011. O controle da transmissão vetorial. Rev Soc Bras Med Trop 44: 52-63.

SILVEIRA AC AND SANCHES O. 2003. Guia para amostragem aplicada a atividades de vigilância e controle vetorial da doença de Chagas, Organização Pan Americana de Saúde, $34 \mathrm{p}$.

VILLELA MM, SOUZA JB, MELLO VP, AZEREDO BVM AND DIAS JCP. 2005. Vigilância entomológica da doença de Chagas na região centro-oeste de Minas Gerais, Brasil, entre os anos de 2000 e 2003. Cad Sau Pub 21: 878-886.

WHO - WORLD HEALTH ORGANIZATION. 1991. Control of Chagas disease. WHO Tech Rep Ser 811: 1-95.

WHO - WORLD HEALTH ORGANiZATION. 2015. Chagas disease in Latin America: an epidemiological update based on 2010 estimates. WHO Tech Rep Ser 6: 33-44. 